University of California, Hastings College of the Law UC Hastings Scholarship Repository

Faculty Scholarship

2013

\title{
Tax-Haven Incorporation for U.S.-Headquartered Firms: No Exodus Yet
}

Susan C. Morse

UC Hastings College of the Law, smorse@law.utexas.edu

Eric J. Allen

Follow this and additional works at: https://repository.uchastings.edu/faculty_scholarship

\section{Recommended Citation}

Susan C. Morse and Eric J. Allen, Tax-Haven Incorporation for U.S.-Headquartered Firms: No Exodus Yet, 66 Nat'l Tax J. 395 (2013). Available at: https://repository.uchastings.edu/faculty_scholarship/1431

This Article is brought to you for free and open access by UC Hastings Scholarship Repository. It has been accepted for inclusion in Faculty Scholarship by an authorized administrator of UC Hastings Scholarship Repository. For more information, please contact wangangela@uchastings.edu. 


\title{
TAX-HAVEN INCORPORATION FOR U.S.-HEADQUARTERED FIRMS: NO EXODUS YET
}

\author{
Eric J. Allen and Susan C. Morse
}

\begin{abstract}
U.S. income tax rules may encourage a U.S.-headquartered multinational corporation (MNC) to adopt a structure with a tax haven parent. We study data from firms that conducted initial public offerings in the United States between 1997 and 2010 and offer evidence that U.S.-headquartered MNCs rarely incorporate in tax havens. Of the 918 U.S.-headquartered MNCs that we identify, only 27 are incorporated in tax havens. Others have pointed to the recent increase in the proportion of firms conducting U.S. IPOs that incorporate in tax havens as possible evidence that more U.S.-headquartered MNCs make this decision. We show instead that Chineseheadquartered firms drive this increase.
\end{abstract}

Keywords: international taxation, initial public offerings, tax havens, headquarters, incorporation

JEL Codes: H25, F23

\section{INTRODUCTION}

ultinational corporations (MNCs) face the challenge of, and opportunity for, multijurisdictional tax planning (Desai and Dharmapala, 2010; Desai, 2009). One primary goal of multijurisdictional planning is to allocate as much taxable income as possible to low-tax jurisdictions, thereby minimizing corporate income tax (Clausing, 2009). While all MNCs have the opportunity to take advantage of this strategy, MNCs with parent corporations incorporated outside the United States, and in particular in tax havens, may have more options available to them (Desai and Hines, 2002). This is because the U.S. corporate residence rule permits a firm incorporated outside the United States to avoid U.S. taxpayer status, even if it is headquartered and managed

Eric J. Allen: Leventhal School of Accounting, University of Southern California, Los Angeles, CA, USA (Eric. Allen@marshall.usc.edu)

Susan C. Morse: University of California Hastings College of the Law, San Francisco, CA, USA (morses@ uchastings.edu) 
in the United States (Shaviro, 2011). Therefore, using a tax-haven-incorporated parent may help U.S.-headquartered MNCs avoid the perceived burdens and anticompetitive features of the U.S. corporate tax system (Donmoyer, 1999; Samuels, 2009) and reduce tax on U.S. and non-U.S. income (U.S. Department of the Treasury (Treasury), 2002). As a result, prior researchers have predicted an increase in U.S.-headquartered firms incorporating in tax havens as a response to onerous U.S. federal income tax rules (Desai and Dharmapala, 2010, Shaviro, 2011).

This paper considers the issue of the incorporation location choice of firms that conduct initial public offerings (IPOs) on U.S. markets. Specifically, it examines whether U.S.headquartered MNCs incorporate in tax havens prior to an IPO. We first consider the hypothesis that U.S.-headquartered MNCs incorporate parent corporations in tax-haven jurisdictions, and find that they rarely do so. In particular, only 27 firms, or about 3 percent of the 918 U.S.-headquartered MNCs that we identify, incorporate in tax havens. We also briefly consider the possibility that U.S.-headquartered MNCs may incorporate in non-U.S., non-tax-haven jurisdictions and find only minimal evidence of this practice in our sample. We next consider whether U.S.-headquartered firms are responsible for the previously documented increase in the proportion of firms conducting U.S. IPOs that are incorporated in tax havens (Desai and Dharmapala, 2010). We find that firms headquartered in China and Hong Kong, as opposed to U.S.-headquartered firms, are largely responsible for the increase. Finally, we list and describe some features of the U.S.-headquartered firms that are incorporated in tax havens, and suggest possible directions for future research.

Section II discusses the different incorporation options for MNCs and the associated costs and benefits. Section III documents our study design, and section IV our results. Section V concludes.

\section{U.S.-HEADQUARTERED MNCs' INCORPORATION DECISIONS}

\section{A. U.S. versus Tax Haven Incorporation}

A U.S.-headquartered MNC faces the choice of whether to incorporate its parent entity in the United States or in a non-U.S. jurisdiction. In this paper we focus on the choice between U.S. and tax-haven incorporation. This is consistent with the hypothesis that if a U.S.-headquartered firm incorporates outside the United States in response to onerous tax rules, it will do so in a tax haven. We consider firms' incorporation decisions prior to the IPO rather than transactions involving inversions of stand-alone U.S.-parented firms into non-U.S.-parented structures.

We begin by discussing the existing laws and incentives that affect U.S.-headquartered, U.S.-incorporated firms and U.S.-headquartered, tax-haven-incorporated firms. We then consider the possibility that incentives to incorporate a tax haven parent have changed or will change over time. Finally, we discuss several non-tax considerations relevant to incorporation decisions. 


\section{B. Tax Structure Options for U.S.-Headquartered MNCs}

\section{Taxation of MNCs with U.S. Parent}

Corporations incorporated in the United States, for example in a U.S. state such as Delaware, are subject to U.S. federal income tax on worldwide income. Because the U.S. tax rules treat separately incorporated affiliates as separate taxpayers, non-U.S. corporate subsidiaries of a U.S. parent are not automatically required to pay U.S. federal income tax. However, a U.S.-parented MNC must currently pay U.S. tax on the income of its foreign subsidiaries to the extent it falls into "subpart F income" categories, which include certain mobile and passive income. When income is repatriated from non-U.S. corporate subsidiaries as dividend distributions, the dividends are included in the income of the U.S. parent. U.S. federal income tax imposed on repatriations, including subpart $\mathrm{F}$ inclusions and dividend distributions, is subject to reduction under applicable foreign tax credit rules. A proportion of foreign income taxes paid by non-U.S. corporate subsidiaries is deemed paid by a U.S. parent upon the U.S. parent's inclusion of subpart $\mathrm{F}$ income or dividend distributions, and these deemed paid foreign taxes can result in foreign tax credits (Isenbergh, 2009).

Like all taxpayers, U.S-parented MNCs face an incentive to engage in tax planning to reduce or defer the amount of U.S. and non-U.S. tax they have to pay. International tax planning differs significantly from firm to firm. However, a typical structure for a U.S.-parented MNC features a U.S. parent corporation, with one or more non-U.S. intermediate holding corporations incorporated in a tax haven or other low-tax jurisdiction, which are owned by the United States parent or by U.S. affiliates of the U.S. parent. The non-U.S. low-tax intermediate holding corporations then own one or more non-U.S. corporate operating subsidiaries (Fleming, Peroni, and Shay, 2009; Kleinbard, 2011a). These structures are facilitated by "check-the-box" entity classification rules finalized by the United States in 1996 (Kleinbard, 2011a).

U.S.-parented MNCs may take advantage of this type of structure by using transfer pricing to construct intercompany transactions in a way that allocates income to the low-tax intermediate holding corporation(s) rather than to the United States or other jurisdictions that assert the right to tax other members of the MNC corporate group. For example, profit may be allocated to a low-tax intermediate holding affiliate because the low-tax affiliate is the owner, for tax purposes, of the MNC's non-U.S. intellectual property (Shay, 2004). The sharing of research and development payments under the so-called "cost sharing" regulations and the transfer of intellectual property offshore at relatively low valuations under the so-called "buy-in" regulations facilitate the ownership of intellectual property by non-U.S. subsidiaries (Brauner, 2008). In addition, MNCs may structure intercompany transactions and external transactions such as contract manufacturing in a way that avoids the characterization of the low-tax affiliate's income as subpart $\mathrm{F}$ income. For example, the low-tax affiliate can be deemed to own a manufactured product throughout its manufacturing process until it is sold to a 
customer (Roin, 2008). Strategies such as these may permit U.S.-parented MNCs to allocate not only non-U.S. income, but also U.S. income, to low-taxed non-U.S. affiliates, and conversely to allocate deductions to U.S. parents (Clausing, 2009; Grubert, 2012).

U.S.-parented MNCs may also use foreign-tax-credit planning to ensure that their repatriations are sheltered from taxation. For example, they may choose to pay dividends from high-taxed rather than low-taxed subsidiaries, generating higher deemed paid foreign taxes. This strategy can shield both dividends and payments other than dividends, such as royalties, from non-U.S. tax (Grubert and Altshuler, 2008). Such MNCs may also use structures that maximize benefits under bilateral income tax treaties and non-U.S. tax laws and ensure that intercompany payments such as royalties and interest are not subject to non-U.S. withholding tax and/or are deductible under non-U.S. income tax law. In addition, alternatives to dividend repatriation, including intercompany loans and "blending" dividends from high-tax and low-tax affiliates, are correlated with the prospect of a high tax liability imposed on dividend repatriation (Altshuler and Grubert, 2002).

As a result of this planning, prior research finds that U.S.-parented MNCs pay low rates of U.S. tax on non-U.S. income earned in non-U.S. subsidiaries. For example, in 2007, U.S.-parented MNCs paid about $\$ 18.1$ billion in U.S. tax with respect to nonU.S. income. This represented an average 3.3 percent residual U.S. tax burden on such income based on 2007 Treasury tax return data (Costa and Gravelle, 2012).

Grubert and Mutti (2001) develop a broader model that calculates the U.S. tax burden on non-U.S. income in U.S.-parented MNC structures including not only taxes remitted but also "excess burden," or deadweight loss. Using this model, based in part on 1992 Treasury tax return data, Altshuler and Grubert (2001) estimate that the effective U.S. tax rate for the non-U.S. income of U.S.-parented MNCs is approximately 5.4 percent. This estimate includes a 1.7 percent "excess burden" deadweight loss generated by unrepatriated earnings in non-U.S. jurisdictions with an effective tax rate below 10 percent, a result that is consistent with other research (Desai, Foley, and Hines, 2001). Grubert and Altshuler (2008) have also raised the possibility that the "implicit costs of deferral" may be greater than 1.7 percent for some firms.

Several costs contribute to the excess burden or deadweight loss of sequestering earnings offshore. For example, lower than optimal dividend payments may limit the ways in which earnings may be invested (Desai, Foley, and Hines, 2001). Additionally, maintaining non-business assets offshore may increase a firm's cost of capital (BryantKutcher, Eiler, and Guenther, 2008). Finally, the firm directly incurs tax planning costs including the expense of creating an offshore structure and maintaining multiple affiliates and intercompany relationships and payments (Slemrod and Blumenthal, 1996).

\section{Taxation of MNCs with Tax-Haven Parent}

An alternative structure features a MNC headquartered in the United States, but whose parent is incorporated in a tax haven that imposes a very low, often zero, rate of corporate income tax. The tax-haven parent typically owns a U.S. subsidiary that 
houses the U.S. management and U.S. business operations of the firm, and also owns other subsidiaries incorporated in non-U.S. jurisdictions (Treasury, 2002). The U.S. rule for corporate tax residence turns on incorporation location, not on the location of management and control (Shaviro, 2011). As a result, a tax-haven-parented MNC avoids exposure to U.S. federal income tax on non-U.S. business income, including subpart F income, earned by non-U.S. subsidiaries (Desai and Hines, 2002).

As mentioned earlier, a U.S.-parented MNC may attempt to allocate not only non-U.S. income, but also U.S. income, to low-taxed non-U.S. subsidiaries (Clausing, 2009; Grubert, 2012). This allocation may lessen the value of tax-haven incorporation. However, tax-haven-parented firms, at least in some cases, have an advantage with respect to this kind of tax planning. Seida and Wempe (2004) and Desai and Hines (2002) suggest that a key benefit of a successful tax-haven-parented MNC structure is the use of earningsstripping strategies, under which a U.S. subsidiary makes deductible interest or other payments to its tax-haven parent to reduce the amount of income subject to U.S. tax. In other words, a tax-haven-parented MNC structure may facilitate the reduction of tax on U.S. income compared to a U.S.-parented MNC structure. In recognition of this issue, a perennial U.S. legislative proposal would tighten anti-earnings-stripping rules for tax-haven-parented MNCs created in inversion transactions (Solomon, 2012).

Prior research provides some evidence of the benefits provided by the tax-havenparented structure. Seida and Wempe (2004) find evidence that earnings stripping by U.S. firms that inverted into tax-haven-parented structures, prior to the enactment of the 2004 anti-inversion rules, resulted in lower post-inversion effective tax rates for the inverted firms compared to a control sample. Cloyd, Mills, and Weaver (2003) find no systematic increase in company valuation following the announcement of an inversion, but Desai and Hines (2002) observe that the markets exhibit more positive reactions to inversions in the presence of greater leverage. The research suggests that a taxhaven-parented structure provides tangible tax savings to some firms, which investors positively value.

Changing from a U.S.-parent to a tax-haven-parent structure is costly, as the applicable rules typically require shareholders to recognize gain (but prevent the recognition of loss) upon such an inversion (Treasury, 2002). Moreover, such a change is sometimes impossible. Under Section 7874 of the Internal Revenue Code, an anti-inversion provision enacted in 2004, a MNC is still treated as a U.S.-parented firm even after acquisition by a foreign corporation if: (1) at least 80 percent of the foreign corporation's stock is owned by former owners of the U.S. parent (by reason of their former ownership of the U.S. parent); and (2) the firm lacks "substantial business activities" in the country in which the new foreign parent is incorporated (Vanderwolk, 2010). Strategic acquisitions continue to provide a path to inversion (Wells, 2012). However, other recently used strategies, such as expatriation to a country where a firm arguably has substantial business activities (Webber, 2011) have been curtailed by recent regulations limiting the definition of substantial business activities. The difficulty of changing incorporation location for an existing U.S.-incorporated firm may increase the incentive for firms to incorporate in a tax haven at inception. 


\section{Increasing Tax-Haven Incorporation Incentives?}

The differences between the federal taxation of U.S.-parented and tax-haven-parented MNCs are not new. But it has been argued that, over time, the differences have become more likely to lead to U.S.-headquartered MNCs opting for tax-haven parents, including at the time of initial incorporation (Desai and Dharmapala, 2010; Shaviro, 2011). One reason is the asserted increased ease, attributable to communications and other technological developments, of "decentering" companies, or placing financial, organizational, and managerial "homes" in different countries (Desai, 2009, p. 1277). Another reason cited for an increased incentive for MNCs to incorporate outside the United States is that other countries have lowered their corporate income tax rates, relative to the United States, partially in an attempt to attract foreign direct investment (Altshuler and Grubert, 2006; Shaviro, 2011). A comparison of the statutory corporate income tax rate imposed by the United States to the statutory rates imposed by other countries reveals that the top U.S. statutory rate of 35 percent substantially exceeds the mean Organisation for Economic Co-operation and Development (OECD) rate of 25 percent, and is much greater than the typical tax-haven rate of 0 percent (Sullivan, 2011). Another factor that firms may consider in connection with tax-haven incorporation is the possibility of future changes in U.S. tax law. For example, in the wake of perceived abuse of the cost-sharing and buy-in regulations mentioned above, the U.S. government adopted revised regulations that had the effect of allocating deductions away from a U.S. parent corporation (in the case of regulations applicable to stock option costs) or allocating income to a parent corporation (in the case of platform contribution transaction buy-in pricing regulations) (Nadal, 2009). Use of a tax-haven parent avoids the possibility that similar rules reducing the ability of a U.S. parent to shift profits to low-tax subsidiaries will adversely affect a firm.

Another reform proposal would change the U.S. corporate income tax system to implement worldwide consolidation, or the current taxation of U.S.-parented MNCs on all of the income generated by non-U.S. subsidiaries (Kleinbard, 2011b), or at least on the income generated by low-taxed non-U.S. subsidiaries (White House and U.S. Treasury, 2012). Such a worldwide consolidation reform would not affect the U.S. federal income taxation of tax haven-parented MNCs.

However, there is also the risk that future tax laws may make tax-haven incorporation less desirable. For example, passage of a "managed and controlled" test for determining corporate residence could significantly undermine the strategy of tax-haven incorporation (Kleinbard, 2011b). Alternatively, rules directed specifically at low-taxed parents of U.S. subsidiaries could undo much of the benefit of, for example, earnings-stripping planning (Solomon, 2012). That said, a tax-haven-parented MNC could presumably domesticate and change into a U.S.-parented MNC if it concluded that the tax-havenparented structure no longer offered sufficient advantages.

\section{Non-tax Considerations}

Non-tax incentives, most importantly capital markets and related corporate governance concerns, can also affect a firm's choice of country of incorporation. Non-U.S. 
incorporation does not offer the benefit of access to Delaware corporate governance law (Kane and Rock, 2008), and this lack of access may translate into lower investor confidence in management (Hanlon and Slemrod, 2009). Related research on the reasons for cross-listing indicates that cross-listed firms trade at a premium because their willingness to comply with stricter accounting, disclosure and other rules serves as a "bonding" signal that reassures investors about low agency costs (Litvak, 2007).

More specific regulatory concerns may also play a role. Certain regulations, like those applicable to the airline industry, may favor U.S.-incorporated firms (Dobson and McKinney, 2009). On the other hand, incorporation outside the United States could facilitate listing outside the United States and the avoidance of some U.S. securities reporting requirements (Litvak, 2007), or could loosen applicable insurance regulations (Elliott, 2005) or shipping law requirements (Semerono, 2000).

These non-tax considerations, together with opportunities for U.S.-incorporated firms to reduce U.S. tax under existing law, may affect the expected benefits of taxhaven incorporation for some firms. However, as pointed out in other research (Desai and Dharmapala, 2010; Shaviro, 2011), tax-haven incorporation still appears to offer many firms the prospect of avoiding a small current U.S. tax on non-U.S. income and the possibility of eroding the U.S. tax base through earnings-stripping strategies. The question we engage is whether firms are taking advantage of this option.

\section{STUDY DESIGN}

\section{A. Overview}

As discussed above, U.S. tax rules may encourage a U.S.-headquartered MNC to adopt a tax-haven-parented structure. But to what extent have U.S.-headquartered MNCs in fact used tax-haven-parented structures, and has their use of these structures changed over time? These questions motivate our study. We seek to test two hypotheses. First, do U.S.-headquartered MNCs incorporate in tax havens prior to an IPO? Second, are U.S.-headquartered firms responsible for the previously documented increase in the proportion of firms conducting U.S. IPOs that are incorporated in tax havens?

\section{B. Use of IPO Data to Study Incorporation Location Decision}

Our study examines firms that conducted IPOs on U.S.-based exchanges between 1997 and 2010. We choose this set of firms because: (1) it has been previously cited as support for the proposition that more U.S.-headquartered MNCs have begun to incorporate outside the United States, and in particular in tax havens (Desai and Dharmapala, 2010; Shaviro, 2011); (2) IPO filings contain not only data about incorporation location and listed headquarters, but also information that can be used to evaluate the "true" natural headquarters of a firm; (3) since IPO firms are often relatively young, use of the IPO sample allows us to observe the incorporation status of many firms relatively close to their original incorporation date; and (4) examining U.S. IPO firms will capture the U.S.-headquartered multinational population that we are interested in, under the assumption that MNCs are large enough to prioritize access to public equity markets. 
Selection bias affects our sample to a limited extent. First, our sample excludes firms that do not conduct an IPO. Therefore we are unable to observe the incorporation decisions of firms who fail, are acquired prior to listing, or remain private. We have little reason to think that firms that fail or experience a strategic acquisition are more likely to choose tax-haven incorporation compared to firms that conduct an IPO. But it is possible that that a firm that plans to stay private may be more likely to choose tax-haven incorporation compared to firms that conduct an IPO. For example, it is possible that corporate governance and shareholders' rights offered by U.S. incorporation are more important for shareholders of a publicly held corporation than for owners of a closely held firm.

A second source of potential bias is that, although our sample includes firms that conduct an IPO on a U.S. exchange simultaneously with an offering on a non-U.S. exchange, we do not examine the incorporation decisions of firms that do not list on a U.S. exchange. There has been a significant drop in IPOs conducted on U.S. exchanges in recent years, and a concurrent increase on non-U.S. exchanges. If this dynamic is driven by U.S.-headquartered firms conducting their IPO on foreign markets, and these firms incorporate in tax havens, then our analysis would undercount the number of U.S.-headquartered firms that incorporate in tax havens.

In concurrent research, Doidge, Karolyi, and Stultz (2012) examine the drivers of the growth of IPOs outside of the U.S. They show that the number of firms conducting an IPO only outside of their domestic market has grown from 55 in 1990 to 734 in 2007, with the associated proceeds increasing from $\$ 8.8$ billion to $\$ 168.8$ billion. While the authors do not document the total number of U.S. firms in this group, they do show that U.S. firms that do not list on a U.S. market generate only 7 percent of the total proceeds from these issuances. They conclude that the growth of IPOs outside the United States is driven predominantly by non-U.S. firms conducting IPOs outside of U.S. exchanges. As a result, we do not believe our focus on U.S.-listed IPO firms omits a meaningful number of U.S.-headquartered MNCs. ${ }^{1}$

A final limitation with our study design is that each observation in our data set typically relates to an incorporation decision taken several years prior to the IPO date and therefore lags incorporation decisions made in response to historical developments. As a result, any decisions made in response to legislative changes in the recent past will most likely not be reflected in the data. For example, the observations of U.S-headquartered, tax-haven-incorporated firms are composed mainly of firms that incorporated prior to the 2004 enactment of I.R.C. Section 7874, which severely curtails the ability of a U.S.-parented MNC to invert into a non-U.S. parent structure.

\footnotetext{
${ }^{1}$ To provide additional evidence that U.S.-headquartered firms generally list on U.S. exchanges, we examined all firms that appear on the Compustat Fundamentals Annual (listed on North American Exchanges) and Global (international exchanges) databases for the sample period of 1997-2010. We identified all firms coded as U.S.-headquartered in the two databases (5,665 firms) and observed that 99 percent (5,622 firms) are, according to the databases, listed on an exchange (item EXCHG for fundamentals annual, EXCHC for global) located in the United States.
} 


\section{Default Incorporation Jurisdiction Assumption}

Others have identified the challenge of identifying the counterfactual case of those firms that would have incorporated in the United States but for U.S. corporate tax rules (Desai and Dharmapala, 2010). We address this problem by assuming that the default jurisdiction of incorporation is the headquarters jurisdiction of the firm. This is consistent with a body of related corporate governance literature that finds a significant homestate advantage and a largely binary incorporation location choice between the home state and Delaware for U.S. firms (Bebchuk and Cohen, 2003; Daines, 2002). Thus a decision by a U.S. firm to incorporate in the United States indicates that corporate tax, regulatory or other incentives are not sufficient to motivate non-U.S. incorporation. Alternatively, a decision by a U.S.-headquartered firm to incorporate in a tax-haven jurisdiction suggests that U.S. tax or other incentives are strong enough to motivate non-U.S. incorporation.

\section{Sample Construction and Identification of Tax Havens}

To build our sample, we collect a listing of all initial public offerings on a stock exchange in the United States from the Thomson Financial Services Database (also known as Securities Data Company (SDC)) between 1997 and 2010. Table 1 details the sample construction. Panel A documents our initial sample of 2,911 IPOs after screening for missing data and eliminating certain investment funds. Panel B documents our collection of U.S.-headquartered firms within the larger sample. We identify 2,587 firms coded by SDC as U.S.-headquartered. We then examine the prospectuses of the 324 firms shown by SDC as headquartered elsewhere to ensure that the nonU.S.-headquartered coding is correct. ${ }^{2}$ We classify all firms that disclose their principal office or more than 50 percent of their employees, floor area, or revenue in the United States as being headquartered in the United States. This results in the identification of 35 additional U.S.-headquartered firms.

Panel C shows our identification of U.S.-headquartered MNCs. We use information provided by the 2011 Compustat fundamentals annual database to find evidence of foreign operations. Table 1, panel C documents this process. Of the 2,622 U.S.headquartered IPO firms, we find 918 firms that show evidence of global operations. We code a firm with the selected screens equal to "missing" as purely domestic. As it is likely that at least some of the "missing" firms have foreign revenues, but do not specifically break out geographic information in their segment disclosures, we are likely undercounting the true number of MNCs.

\footnotetext{
2 The SDC "Nation" coding generally simply refers to the principal executive office listing on the face of the registration statement, which may not reflect a firm's strongest business nexus. Of the 302 non-U.S.incorporated firms for which we hand-collected principal executive office data, 277, or 92 percent, listed a principal executive office country that was the same as the SDC "Nation" code.
} 


\section{Table 1}

\section{Sample Construction}

Panel A: Total Sample

Total U.S. IPOs, between 1997-2010, from SDC

Less:

Non-original IPOs

Duplicate entries

Firms for which we could not obtain the country of incorporation

SIC code filters:

6000-6199: Depository and non-depository credit institutions

6722: Open-end management investment offices

6726: Closed-end management investment offices

6798: Real estate investment funds

$-107$

6799: Other investors

Initial sample

Panel B: Construction of U.S.-headquartered Sample

Total U.S.-headquartered Firms per SDC Coding

Added from review of prospectuses:

Principal executive office listed $=$ U.S.

More than $50 \%$ U.S. revenue

More than 50\% floor area in U.S.

More than 50\% U.S. employees

Total U.S.-headquartered Firms

Panel C: Constructions of U.S.-headquartered MNC Sample

Total U.S.-headquartered Firms

Number that could be Identified in Compustat

U.S.-headquartered Firms with Non-missing, Non-zero Amounts

in the Year of IPO or any of the Subsequent Three Years:

Pre-tax foreign income

Foreign deferred taxes

Foreign income tax expense 


\section{Table 1 (continued) \\ Sample Construction}

Notes: Firms identified as U.S.-headquartered MNCs in Panel C are used for the analysis in Table 2. Firms identified as U.S.-headquartered MNCs in Panel $\mathrm{C}$ and that also provide information regarding pre-tax foreign income (PIFO) and total pre-tax income (PI) are segregated for the analysis in Table 4.

Sources:

Panel A:

We obtain a listing of all Initial public offerings in the United States from the Thomson Financial Services Database (Securities Data Company (SDC)) between 1997 and 2010. This results in 3,939 offerings. From SDC we obtain the firm name, issue date, SIC code, country of incorporation (item "Country of Incorporation" or "State of Incorporation"), and headquarters country (item "Nation"). We eliminate all offerings which were not the firms' initial IPO (SDC category "Original IPO" equal to "No"), as well as 18 offerings that are duplicated in the database. We note 899 offerings that are missing the country of incorporation in SDC. For these offerings we manually review the firms' prospectus (i.e. form S-1, F-1, $\mathrm{S}-11, \mathrm{~N}-2$, etc.) to collect the country of incorporation at the time of offering. We obtain this information for all but 259 of the offerings. We also eliminate all depository and non-depository credit institutions (SIC Codes 6000-6199), real estate investment trusts (6798), closed-end management investment offices (6726), open-end management investment offices (6722), and other investors (6799). This leaves us with 2,911 firms with the countries of headquarters and incorporation identified.

\section{Panel B:}

We note that SDC typically uses the address given by the firm as the principal executive office to determine the headquarters country. To expand the definition of U.S.-headquartered firms, we review the prospectuses for all 324 firms not incorporated in the United States to find evidence that the firm is effectively domiciled in the United States. We apply four screens to make this determination: (1) address of the principal executive office; (2) percentage of employees located in the United States; (3) percentage of floor area located in the United States; and (4) percentage of revenue generated in the United States. For the last three screens, if the percentage is greater than $50 \%$, we code the firm as having a headquarters in the United States. This results in coding an additional 35 firms as U.S.-headquartered.

\section{Panel C:}

We use the firm's CUSIP number from SDC to obtain the GVKEY from the 2011 version of the Compustat fundamentals annual database. For firms that could not be identified in this manner we collect the CIK number from the SEC's EDGAR database and use it to identify the GVKEY in Compustat. For each firm we obtain the ending total assets (item AT), closing share price (PRCC_F), common shares (CSHO), and net income (NI) for the first fiscal year end after the conclusion of the IPO. We require that each firm have non-missing item AT for inclusion in the sample, leaving 2,465 firms available for analysis. For these firms we code each that reports a non-zero amount of pre-tax foreign income (Compustat item PIFO), foreign deferred tax liability (item TXDFO), or foreign tax expense (item TXFO) in the year of IPO or the subsequent three years as having foreign operations. If all of those amounts are zero or missing we code the firm as having solely domestic income. 


\section{RESULTS}

\section{A. Summary}

Our results are divided into three sections. First, we report the frequency with which U.S.-headquartered MNCs in our data set incorporate in tax-haven jurisdictions. We consider a firm to be incorporated in a tax haven if the incorporation country is classified as such by Dharmapala and Hines (2009). ${ }^{3}$ We also show descriptive data comparing U.S.-headquartered MNCs with tax-haven-incorporated parents to U.S.-headquartered MNCs with U.S.-incorporated parents. Second, we examine the previously noted increase of U.S.-listed IPO firms incorporating in tax havens (Desai and Dharmapala, 2010), and document where the firms driving this increase are headquartered. Finally, we list and describe the characteristics of the U.S.-headquartered firms that we find are important in the decision to incorporate in a tax-haven jurisdiction.

\section{B. U.S.-Headquartered MNCs Overwhelmingly Incorporate in the United States}

In this paper, we generally consider U.S.-headquartered firms' incorporation decisions as a binary choice between U.S. incorporation and tax-haven incorporation. A third choice, non-U.S., non-tax-haven incorporation, is also an option. Some anecdotal evidence of recent examples of the approach of non-U.S., non-tax-haven incorporation exists (Webber, 2011). Before turning to the United States-versus-tax-haven choice, we briefly consider the possibility that multinational firms in our sample choose to incorporate outside the United States, but not in tax havens, by examining the 918 U.S.-headquartered MNCs that we identify.

Table 2 presents the results. Of the 918 identified U.S.-headquartered MNCs in the sample, 44 incorporate outside the United States. Of these 44 firms, 17, or 2 percent of the total sample, incorporate in a non-U.S. country that is not a tax haven. ${ }^{4}$ Israel is the only non-tax-haven country with more than a 1 percent share of the firms that incorporate outside the United States. Therefore, while the results indicate that a U.S.headquartered MNC is overwhelmingly likely to incorporate in the United States, if it does not, it is most likely to incorporate in a tax haven.

\footnotetext{
3 The Dharmapala and Hines list represents the consolidation of two different lists, one from Hines and Rice (1994) and one from an OECD (2000) report. A firm is classified as being incorporated in a tax haven jurisdiction if the 2-digit country code corresponds to a country listed as a tax haven (Dharmapala and Hines, 2009). These countries are: Andorra, Anguilla, Antigua and Barbuda, Aruba, Bahamas, Bahrain, Barbados, Bermuda, British Virgin Islands, Cayman Islands, Channel Islands, Cook Islands, Cyprus, Dominica, Gibraltar, Hong Kong, Ireland, Isle of Man, Jordan, Lebanon, Liberia, Lichtenstein, Luxembourg, Macao, Maldives, Malta, Marshall Islands, Mauritius, Monaco, Montserrat, Nauru, Netherland Antilles, Niue, Panama, Saint Kitts and Nevis, Saint Lucia, Saint Vincent and the Grenadines, Samoa, San Marino, Seychelles, Singapore, Switzerland, Tonga, Turks and Caicos Islands, Vanuatu, and Virgin Islands (U.S.).

${ }^{4}$ We obtain similar figures when we consider the total sample of U.S.-headquartered firms without controlling for MNC status: only 69 firms, or 2.6 percent of the larger sample, incorporate outside the United States and 22 of these 69 firms incorporate in a non-U.S., non-tax-haven location.
} 


\section{Table 2}

Incorporation Locations of U.S.-Headquartered MNCS

\begin{tabular}{lcc}
\hline Country of Incorporation & Number & Percentage of Total \\
\hline United States & 874 & 95 \\
Tax Haven & 27 & 3 \\
Israel & 10 & 1 \\
Canada & 3 & 0.3 \\
Netherlands & 2 & 0.2 \\
Germany & 1 & 0.1 \\
Philippines & 1 & 0.1 \\
\hline Total & 918 & \\
Notes: See Table 1 for sample description. A firm is classified as incorporated in a tax haven juris- \\
diction if the 2 digit country code corresponds to a country listed as a tax haven by Dharmapala \\
and Hines (2009, p. 1067); see footnote 3 for a list of these countries.
\end{tabular}

We focus the remainder of our analysis on the choice between tax-haven and U.S. incorporation. This focus not only includes the majority of non-U.S. incorporation location choices made by U.S.-headquartered MNCs, but also responds directly to the prediction of an increase in U.S.-headquartered, tax-haven-incorporated firms as a result of onerous U.S. federal income tax rules (Desai and Dharmapala, 2010; Shaviro, 2011). Table 3 shows the number of MNCs headquartered in the United States that incorporate in a tax haven compared to the total number of MNCs headquartered in the United States and incorporated in the United States or a tax haven. Table 3's analysis does not include the $17 \mathrm{MNCs}$ headquartered in the U.S. and incorporated in non-U.S., non-tax-haven locations. The overall number of tax-haven-incorporated firms in this subsample of issuers is only 27 out of 901 , or 3 percent. Even if we assume that the additional 20 tax-haven firms that were missing evidence of foreign operations in Compustat are multinationals, and that no non-tax-haven firms missing information were multinationals, the percentage of U.S.-headquartered MNCs that choose to incorporate in tax havens would only increase to just over 5 percent.

In some years, the percentage of tax-haven-incorporated firms is higher. For example, it is 16 percent in 2002 and 9 percent in 2009. However, in both of those years, the absolute number of tax-haven firms is only three and two, respectively. The higher percentage in those years reflects the low number of total IPOs as opposed to an increase in the occurrence of U.S. MNCs incorporating in tax havens. The results indicate that U.S.-headquartered MNCs have not made the decision to incorporate in tax havens prior to an IPO in significant numbers.

As noted in Panel C of Table 1, of the 918 multinational, U.S.-headquartered IPO firms that we identify, 588 have sufficient information about non-U.S. income to permit a comparison of the financial characteristics of different firms. In keeping with our binary 


\begin{tabular}{|c|c|c|c|}
\hline \multicolumn{4}{|c|}{$\begin{array}{c}\text { Comparison of U.S-Headquartered MNCs that Incorporate in Tax } \\
\text { Havens to Total U.S.-Headquartered MNCs that Incorporate in the } \\
\text { United States or in Tax Havens }\end{array}$} \\
\hline \multirow[b]{2}{*}{ Year } & \multicolumn{3}{|c|}{ Incorporated in a Tax Haven } \\
\hline & Total & Number & Percentage \\
\hline 1997 & 139 & 3 & 2 \\
\hline 1998 & 78 & 0 & 0 \\
\hline 1999 & 127 & 1 & 1 \\
\hline 2000 & 120 & 4 & 3 \\
\hline 2001 & 37 & 1 & 3 \\
\hline 2002 & 19 & 3 & 16 \\
\hline 2003 & 22 & 1 & 5 \\
\hline 2004 & 74 & 1 & 1 \\
\hline 2005 & 65 & 3 & 5 \\
\hline 2006 & 70 & 3 & 4 \\
\hline 2007 & 80 & 3 & 4 \\
\hline 2008 & 8 & 0 & 0 \\
\hline 2009 & 23 & 2 & 9 \\
\hline \multirow[t]{2}{*}{2010} & 39 & 2 & 5 \\
\hline & 901 & 27 & 3 \\
\hline
\end{tabular}

comparison, we focus on a subsample of 575 firms that are incorporated either in a tax haven or in the United States for the analysis. As Table 4 shows, 19 of these 575 firms are incorporated in a tax haven. Compared to firms not incorporated in tax havens, the tax-haven firms have significantly larger average assets $\left(A S S E T S_{t}\right.$ of $\$ 1.7$ billion versus about $\$ 800$ million) and market capitalization ( $S I Z E_{t}$ of $\$ 3.1$ billion versus $\$ 1.3$ billion). They are also more profitable, as average return on assets $\left(I N C_{t}\right)$ in the year of the IPO is 0.03 versus -0.04 for the U.S.-incorporated firms. Our data show research and development intensity $(\mathrm{R} \& \mathrm{D})$ that is slightly higher for U.S.-incorporated firms, but this difference is not statistically significant.

Finally, the tax-haven incorporated firms have a higher ratio of foreign income to total income (FORINC of 0.64 versus 0.23 ). This suggests that the U.S.-headquartered firms that incorporate in tax havens are the firms that expect to realize relatively larger benefits from the reduction of U.S. tax on their non-U.S., and perhaps also their U.S., 


\begin{tabular}{|c|c|c|c|}
\hline \multicolumn{4}{|c|}{$\begin{array}{l}\text { Mean Values for Selected Financial Variables for MNCs } \\
\text { Headquartered in the United States } \\
\text { (\$Million) }\end{array}$} \\
\hline \multirow[b]{2}{*}{ Variable } & \multicolumn{2}{|c|}{ Incorporation Location } & \multirow[b]{2}{*}{ Difference } \\
\hline & US & Tax Haven & \\
\hline ASSETS $_{\mathrm{t}}$ & 832.9 & $1,725.4$ & $892.5^{* *}$ \\
\hline $\operatorname{SIZE}_{t}$ & $1,295.9$ & $3,141.2$ & $1,845.3^{*}$ \\
\hline $\mathrm{INC}_{\mathrm{t}}$ & -0.04 & 0.03 & $-0.07 *$ \\
\hline FORINC & 0.23 & 0.64 & $-0.41 * * *$ \\
\hline $\mathrm{RD}$ & 0.09 & 0.05 & 0.03 \\
\hline $\mathrm{N}$ & 556 & 19 & \\
\hline \multicolumn{4}{|c|}{ 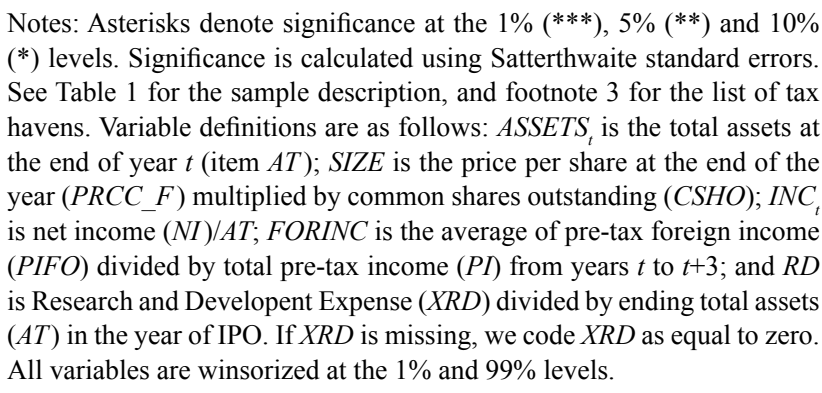 } \\
\hline
\end{tabular}

income. However, the results also show that U.S.-incorporated MNCs still exhibit material foreign operations (FORINC of 0.23 ) which indicates that there may be a substantial number of U.S.-headquartered firms that could reap some tax benefits from incorporating in a tax haven, yet do not make that choice.

\section{Chinese- and Hong Kong-Headquartered Firms Drive Increase in Tax-Haven- Incorporation Trend}

We next examine the hypothesis that U.S.-headquartered firms are responsible for the previously documented increase in the proportion of firms conducting U.S. IPOs that are incorporated in tax havens (Desai and Dharmapala, 2010). We use the larger sample of all U.S. IPOs from 1997-2010, as shown in panel A of Table 1, to consider this question. The use of the larger sample, not screened for evidence of multinational activity, is consistent with the approach in Desai and Dharmapala. 
Table 5 provides a breakdown of the U.S. IPO firms that incorporate in tax havens. We find that Chinese-, Greek-, and Hong Kong-headquartered firms are responsible for about 60 percent of the instances of tax-haven-incorporated firms conducting U.S. IPOs. Chinese- and Hong Kong-headquartered firms make up more than half of such firms, or 111 out of 210 .

Figure 1 duplicates the results obtained by Desai and Dharmapala (2010) and shows that the proportion of U.S. IPO firms incorporated in tax havens increased dramatically around 2002. But, as Figure 1 also shows, the frequency of U.S.-headquartered firms incorporating in tax havens has increased only slightly over our sample period. Chineseand Hong Kong-headquartered issuers, not U.S.-headquartered issuers, drive the recent dramatic proportional increase in tax-haven-incorporated firms conducting U.S. IPOs.

The finding that Chinese- and Hong Kong-headquartered firms regularly incorporate in tax-haven jurisdictions ${ }^{5}$ has possible relevance to future research about whether U.S.-headquartered firms might at some point begin to regularly incorporate in tax havens or, more generally, outside the United States. In the case of Chinese- and Hong Kong-headquartered firms, there are several non-tax reasons that may support tax haven incorporation. These include legislative restrictions relating to foreign ownership of Chinese-incorporated firms, shareholder and creditor rights, listing approval, and foreign exchange convertibility (Howson and Khanna, 2010). In addition, the high quality and

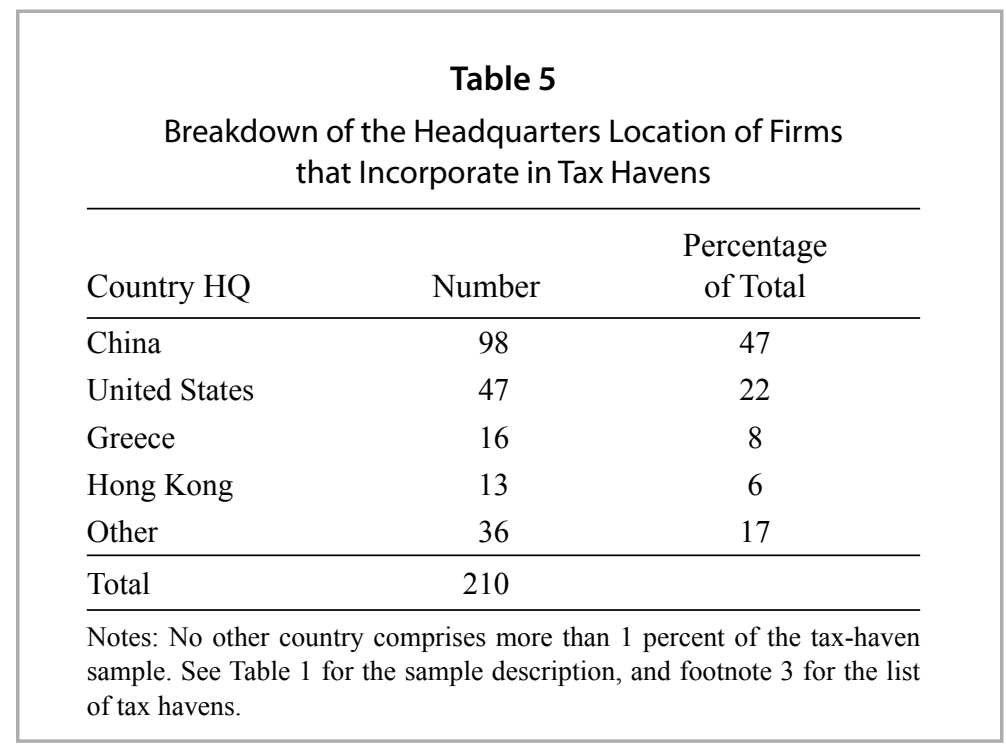

\footnotetext{
${ }^{5}$ We also find that Chinese and Hong Kong firms are responsible for more than half (124 out of 243) of the instances of corporations incorporating outside their headquarters jurisdiction - whether or not in a tax haven - and that the overwhelming majority (111 out of 124) of those instances involve incorporation in a tax haven.
} 


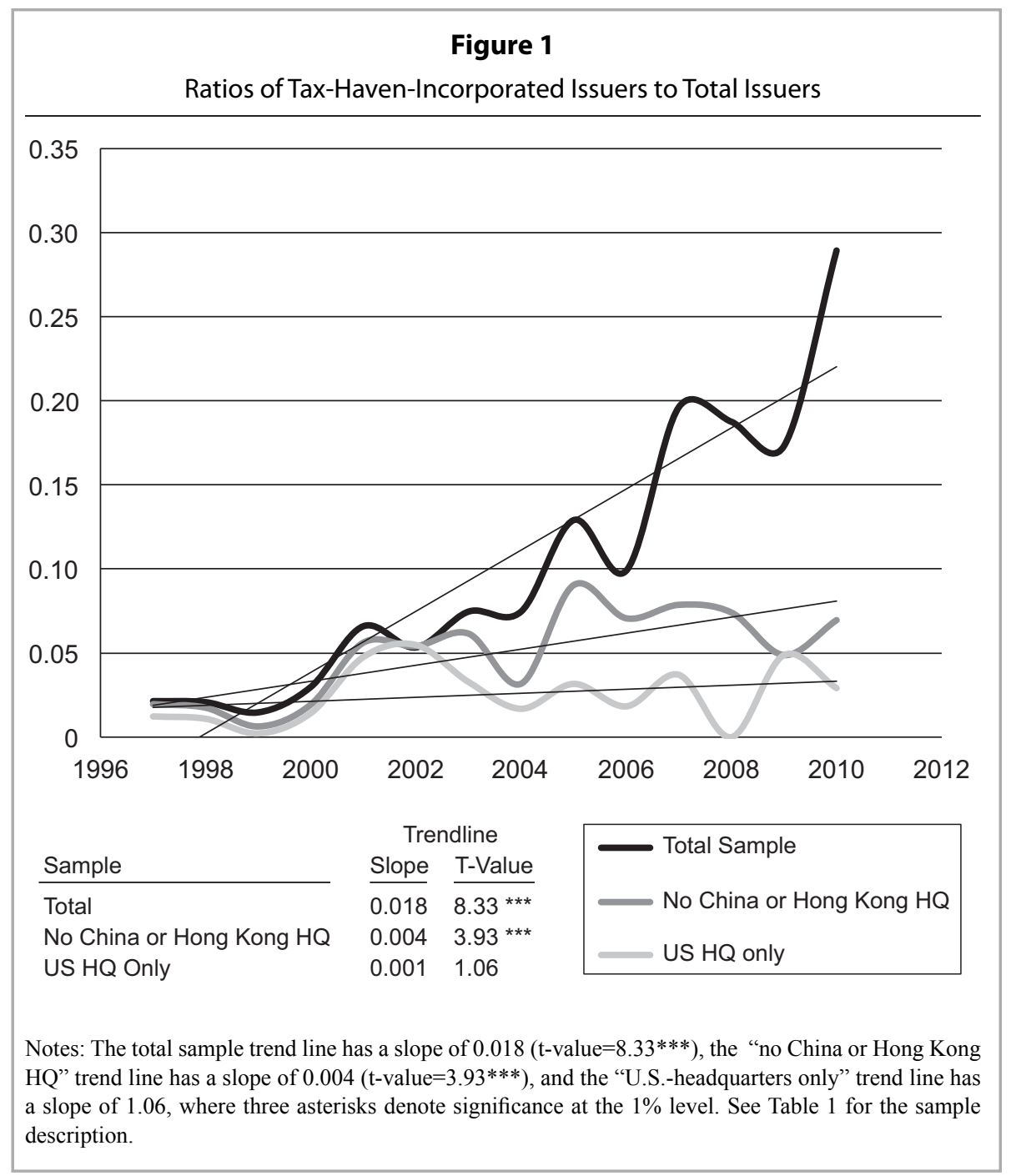

flexibility of tax havens' corporate governance regimes may increase the attractiveness of tax-haven incorporation (Dharmapala and Hines, 2009).

Tax considerations may also play a role. First, the tax savings attributable to tax havens' low or zero corporate tax rates increases the likelihood of tax-haven incorporation rather than incorporation in the U.S. or other countries. Domestic tax issues may also have relevance. Prior to the repeal of Chinese foreign direct investment incentives in 2007, Chinese investors had an incentive to "round-trip" their capital into China using nonChinese investment vehicles to take advantage of these incentives (Li, 2007). Even after 
the repeal of this law, advisors may still continue to use tax-haven-parented corporate structures because of habit or path dependence.

With the above discussion we are not attempting to conclusively answer the question as to why Chinese- and Hong Kong-based firms have increasingly incorporated in tax havens. Rather, by introducing possible reasons for this development we hope to suggest directions for future research into the question of why some firms incorporate in tax havens, and others do not.

\section{U.S.-Headquartered, Tax-Haven-Incorporated Firms}

We identify 47 U.S.-headquartered, tax-haven-incorporated firms in our larger sample of 2,911 MNCs. ${ }^{6}$ Table 6 lists these firms. In each case, a number of tax and non-tax decisions could have influenced the tax-haven-incorporation decision. We do not claim that tax considerations were the predominant driver for any of these firms' incorporation decision. Rather, we propose that the existence of these 47 firms leaves open the possibility that tax advantages of tax-haven incorporation may be influential factors in incorporation decisions for at least some firms. Of these 47 firms, 17 incorporated in, or after, 2004, the year in which the U.S. enacted stringent anti-inversion legislation.

First, we observe a tendency of U.S.-headquartered corporations in particular lines of business, such as insurance or marine transportation, to incorporate in tax-haven locations. Of the 47 firms, 13 are insurance carriers, and four are engaged in marine transportation. For both of these industries, specific and favorable tax provisions suggest that corporate tax incentives provide some of the reasons for firms' choice of tax-haven-parented structures.

In the case of insurance, it is possible for a tax-haven parent to minimize taxation on passive portfolio income such as interest and dividends, in part because of the low or zero tax-haven rate. A tax-haven parent may also avoid having any business income taxed by the United States and may arrange for the U.S. subsidiary to make deductible payments to the tax-haven parent, thus eroding the income tax base of the U.S. subsidiary. If the tax-haven parent is incorporated in Bermuda, the goal of avoiding taxation of the tax-haven parent by the United States may be facilitated by tax treaties that permit the use of a taxpayer-favorable permanent establishment provision specifically applicable to the insurance business (Elliott, 2005). Section 4371 of the Internal Revenue Code imposes excise taxes on premiums paid to a foreign insurer of 4 percent for some policy types including property and casualty and 1 percent for reinsurance and other policy types including life insurance. These excise taxes are subject to reduction under tax treaties, although IRS guidance limits the extent to which tax treaty relief can be claimed (Ocasal, Miles, and Tello, 2009). In some cases, premiums paid to a foreign reinsurer may escape state excise tax; non-tax regulatory concerns, such as the possibility of relaxed investment requirements, may also encourage tax-haven incorporation for some insurance firms (Bissell, 2003).

${ }^{6}$ Largely because of missing data fields, not all of these 47 firms appear in our subsample of 918 U.S.headquartered multinational firms. We manually collect incorporation year data for these 47 firms from publicly available documents. 


\section{Table 6}

U.S.-Headquartered, Tax-Haven-Incorporated U.S.-IPO Firms, 1997-2010

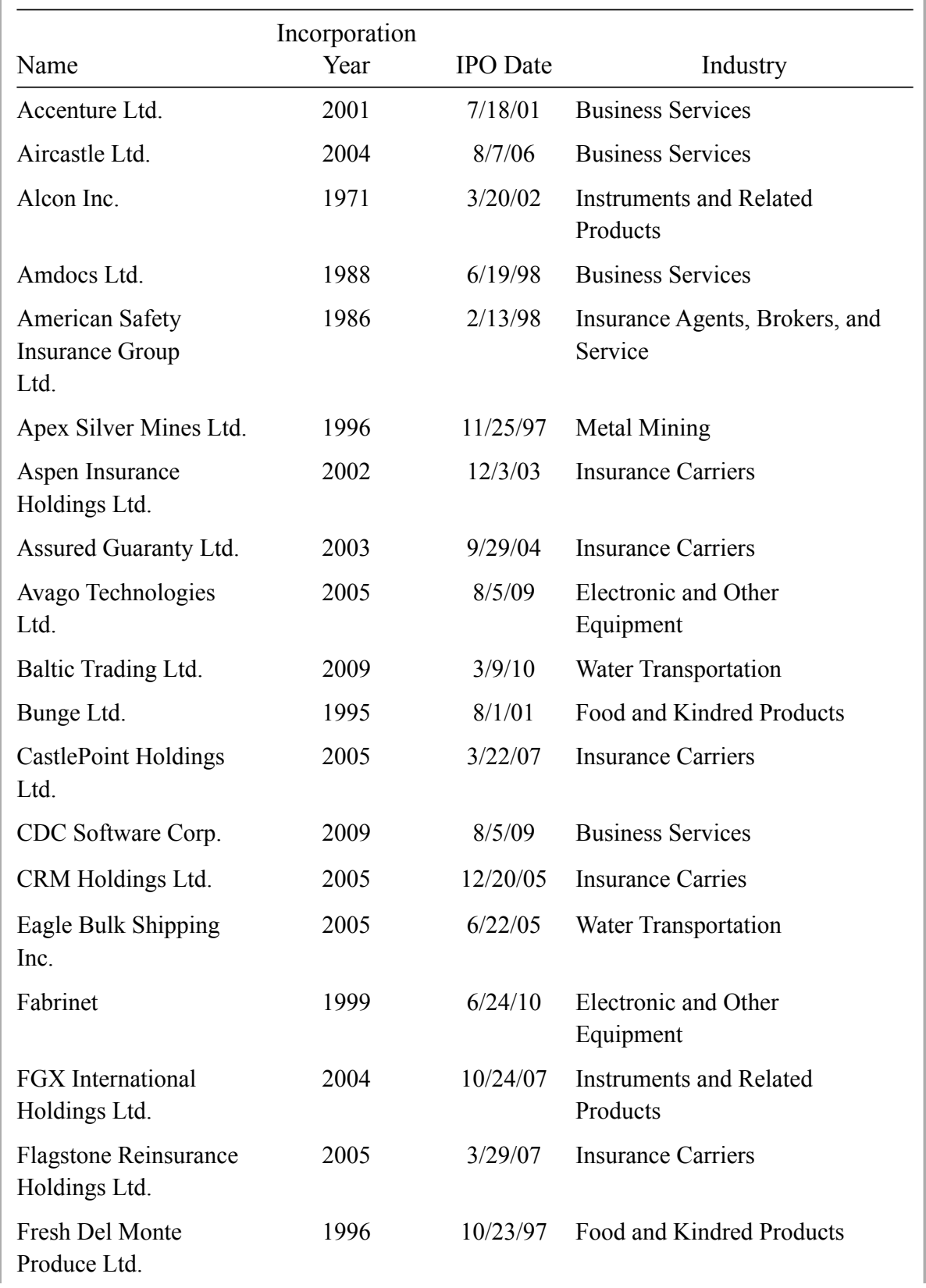




\section{Table 6 (continued)}

U.S.-Headquartered, Tax-Haven-Incorporated U.S.-IPO Firms, 1997-2010

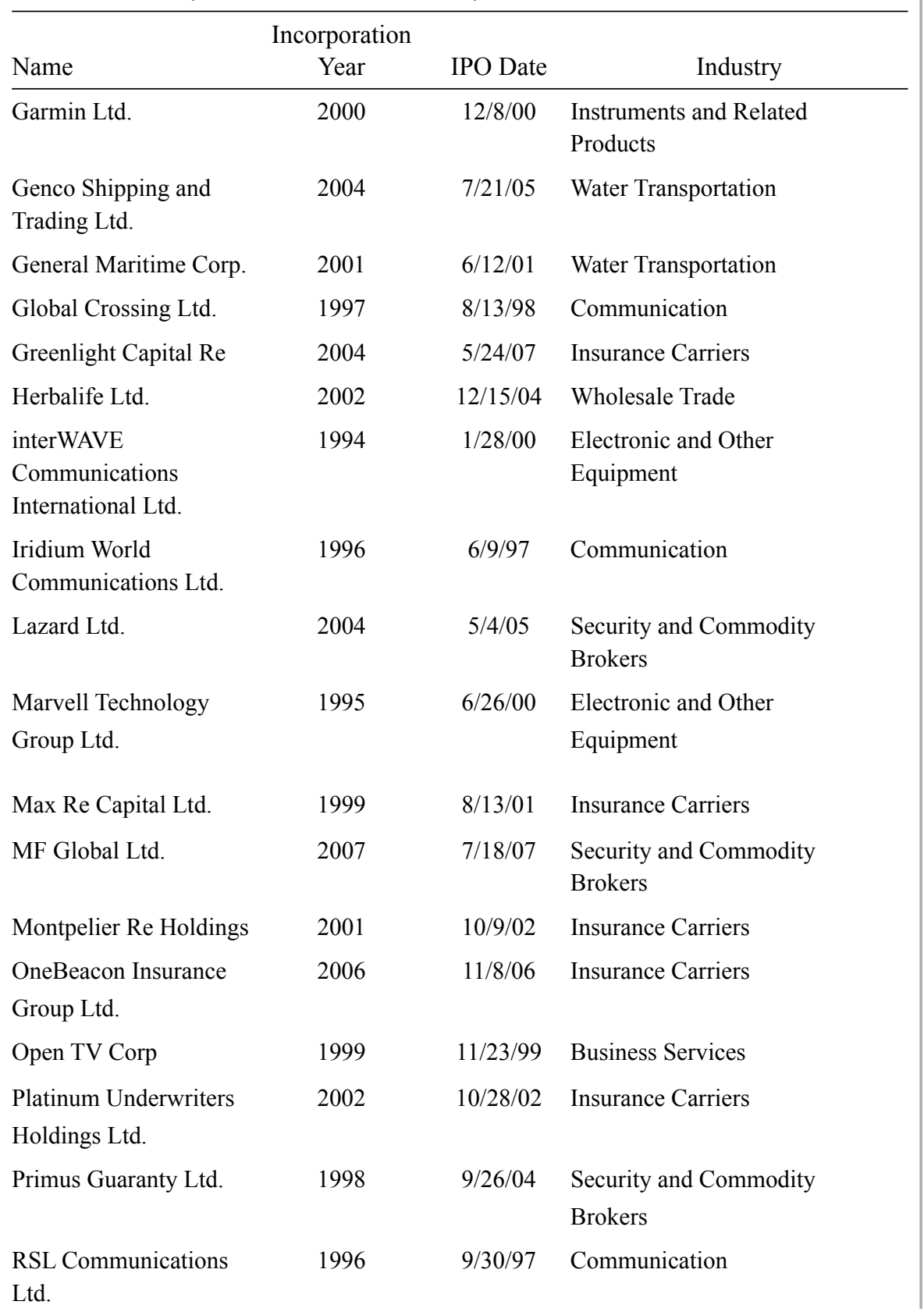




\section{Table 6 (continued)}

U.S.-Headquartered, Tax-Haven-Incorporated U.S.-IPO Firms, 1997-2010

\begin{tabular}{lccl}
\hline Name & $\begin{array}{c}\text { Incorporation } \\
\text { Year }\end{array}$ & IPO Date & \multicolumn{1}{c}{ Industry } \\
\hline $\begin{array}{l}\text { Santa Fe International } \\
\text { Corp. }\end{array}$ & 1990 & $6 / 9 / 97$ & Oil and Gas Extraction \\
$\begin{array}{l}\text { SeaCube Container } \\
\text { Leasing Ltd. }\end{array}$ & 2010 & $10 / 27 / 10$ & Business Services \\
Seagate Technology & 2000 & $12 / 10 / 02$ & Industrial Machinery and \\
Holdings & & & Equipment \\
Stirling Cooke Brown & 1995 & $11 / 25 / 97$ & Insurance Carriers \\
Holdings Ltd. & & & \\
TyCom Ltd. & 2000 & $7 / 26 / 00$ & Communication \\
United National Group & 2003 & $12 / 15 / 03$ & Insurance Carriers \\
Ltd. & & & \\
UTi Worldwide Inc. & 1995 & $11 / 2 / 00$ & Transportation Services \\
Validus Holdings Ltd. & 2005 & $7 / 24 / 07$ & Insurance Carriers \\
Vistaprint Ltd. & 2002 & $9 / 29 / 05$ & Printing and Publishing \\
Warner Chilcott & 2004 & $9 / 20 / 06$ & Chemicals and Allied \\
Holdings Co. Ltd. & & Products \\
& & &
\end{tabular}

Shipping companies with tax-haven parents can take advantage of a different provision of U.S. law, which exempts income from the international operation of a ship from U.S. income tax if earned by a foreign corporation resident in a country that declines to tax similar income earned by U.S. corporations (Glicklich and Miller, 2012). Regulatory reasons may also encourage the use of non-U.S. shipping flags for certain types of shipping businesses. U.S. statutory law limits some commerce, such as "coastwise" shipping between two U.S. ports, to U.S.-flagged vessels. For commerce not so limited, non-U.S. registration may provide an advantage for non-tax regulatory reasons including possible avoidance of applicable labor regulations, union contracts, and requirements to use U.S. shipyards for vessel construction (Semenoro, 2000) as well as avoiding exposure to the choice of law doctrine that may require a U.S. forum in the event of worker injury for a U.S.-registered ship (Gilmore and Black, 1975).

Other companies, not in the insurance or shipping industries, appear to have made an internal decision to incorporate in tax havens. These include Accenture Ltd., the Arthur 
Andersen consulting spinoff, Lazard Ltd., the investment bank, and TyCom Ltd., a spinoff from Tyco International, which had previously expatriated (Desai and Hines, 2002). They also include Fresh Del Monte Produce Ltd. and Bunge Ltd., companies with significant agricultural operations outside the United States.

Finally, several of the companies we study conducted IPOs after a going-private transaction previously established a tax-haven parent. These include Seagate Technology Holdings and Herbalife Ltd. The going-private transactions highlight the possibility that market participants such as private equity investors, or advisors such as particular law firms or investment banks, influence the decision to incorporate in a tax haven. Analogous market participant influence appears to affect some other firm decisions, such as those relating to takeover defense (Coates, 2001) and the use of "supercharged IPO” structures (Fleischer and Staudt, 2012).

There are at least two interesting aspects of the market participant story. First, it is possible that some market participants have specific interests or priorities that encourage tax-haven incorporation. Private equity firms might prioritize tax savings over corporate governance protections, for example. Second, if the decision to incorporate in a tax haven is mediated by communities of market participants, or their advisors that share advice and norms and imitate structures, this may affect how a change in behavior might come about. For example, a change in U.S.-based startups' incorporation decisions may gather momentum quickly if an influential group of investors or advisors concludes that the default jurisdiction of incorporation for U.S. startups should be outside the United States.

\section{CONCLUSION}

Using data on firms conducting IPOs in the United States between 1997 and 2010, we examine two hypotheses. First, we consider whether U.S.-headquartered MNCs incorporate in tax havens, and provide evidence that they do not. Out of the 918 U.S.headquartered MNCs that we identify, only 27 incorporate in tax havens. This suggests that some firms that could benefit from tax savings provided by tax-haven incorporation do not take advantage of this strategy.

Second, we test the hypothesis, suggested in Desai and Dharmapala (2010), that a recent increase in the proportion of U.S. IPO firms incorporated in tax havens shows that U.S.-headquartered firms have increasingly begun to incorporate in tax havens. To test this second hypothesis, we use a larger sample of 2,911 firms. We find that the proportion of firms conducting IPOs in the United States that are incorporated in tax havens began to increase around 2002, consistent with Desai and Dharmapala. However, we find that only 47 U.S.-headquartered firms incorporate in a tax haven, and that firms headquartered outside the United States, in particular, in China and Hong Kong, drive the trend of increasing incorporation in tax havens.

Future research might focus on providing a better idea of how firms make incorporation location decisions. In particular, better defining how capital formation and home or host country corporate governance and regulatory regimes impact the choice of incorpora- 
tion would help provide a better framework for evaluating how tax regimes influence incorporation location choice. Additionally, studying institutional factors, such as the variance of incorporation location choice cross-sectionally across industries, may help predict how firms will respond to changes in tax or other rules.

\section{ACKNOWLEDGMENTS AND DISCLAIMERS}

Many thanks for helpful comments to editors William Gentry and George Zodrow and two anonymous referees; and to commentators and participants at the National Tax Association 2011 Annual Meeting, the American Tax Policy Institute Conference on International Taxation and Competitiveness, the University of California Hastings Traynor Summer Workshop, and the 2011 Critical Tax Conference.

\section{REFERENCES}

Altshuler, Rosanne, and Harry Grubert, 2001. "Where Will They Go If We Go Territorial? Dividend Exemption and the Location Decisions of Multinational Corporations." National Tax Journal 54 (4), 787-810.

Altshuler, Rosanne, and Harry Grubert, 2002. "Repatriation Taxes, Repatriation Strategies and Multinational Financial Policy.” Journal of Public Economics 87 (1), 73-107.

Altshuler, Rosanne, and Harry Grubert, 2006. "The Three Parties in the Race to the Bottom: Host Governments, Home Governments and Multinational Corporations." Florida Tax Review 7 (3), 137-209.

Bebchuk, Lucian A., and Alma Cohen, 2003. “Firms' Decisions Where to Incorporate.” Journal of Law and Economics 46 (2), 383-425.

Bissell, Thomas S. G., 2003. "A Comparison of the U.S. Tax Rules for U.S. and Offshore Insurance Products.” Tax Management International Journal 32 (1), 14-32.

Brauner, Yariv, 2008. "Value in the Eye of the Beholder: The Valuation of Intangibles for Transfer Pricing Purposes.” Virginia Tax Review 28 (1), 79-164.

Bryant-Kutcher, Lisa Eiler, and David A. Guenther, 2008. "Taxes and Financial Assets: Valuing Permanently Reinvested Earnings.” National Tax Journal 61 (4), 699-720.

Clausing, Kimberly A., 2009. "Multinational Firm Tax Avoidance and Tax Policy." National Tax Journal 62 (4), 703-725.

Cloyd, C. Brian, Lillian F. Mills, and Connie D. Weaver, 2003. "Firm Valuation Effects of the Expatriation of U.S. Corporations to Tax Haven Countries." Journal of the American Taxation Association 25 (1), 87-109.

Coates, John C., IV, 2001. "Explaining Variation in Takeover Defenses: Blame the Lawyers." California Law Review 89 (5), 1301-1421. 
Costa, Melissa, and Jennifer Gravelle, 2012. "Taxing Multinational Corporations: Average Tax Rates." Tax Law Review 65 (3), 391-414.

Daines, Robert, 2002. "The Incorporation Choices of IPO Firms." New York University Law Review 77 (6), 1559-1661.

Desai, Mihir A., 2009. "The Decentering of the Global Firm." The World Economy 32 (9), 1271-1290.

Desai, Mihir A., and Dhammika Dharmapala, 2010. "Do Strong Fences Make Strong Neighbors?" National Tax Journal 63 (4), 723-740.

Desai, Mihir A., C. Fritz Foley, and James R. Hines Jr., 2001. "Repatriation Taxes and Dividend Distortions.” National Tax Journal 54 (4), 829-852.

Desai, Mihir A., and James R. Hines Jr., 2002. "Expectations and Expatriations: Tracing the Causes and Consequences of Corporate Inversions." National Tax Journal 55 (3), 409440 .

Dharmapala, Dhammika, and James R. Hines Jr., 2009. "Which Countries Become Tax Havens?" Journal of Public Economics 93 (9-10), 1058-1068.

Dobson, Alan P., and Joseph A. McKinney, 2009. "Sovereignty, Politics and U.S. International Airline Policy." Journal of Air Law and Commerce 74 (3), 527-552.

Doidge, Craig, George Andrew Karolyi, and Rene M. Stulz, 2012. "Financial Globalization and the Rise of IPOs Outside the U.S." Working Paper No. 2012-13. Ohio State University Fisher College of Business, Columbus, $\mathrm{OH}$.

Donmoyer, Ryan, 1999. "Multinationals Beg Finance to Simplify International Laws.” Tax Notes 82 (11), 1539-1540.

Elliott, William P., 2005. “A Guide to Captive Insurance Companies.” Journal of International Taxation 16 (7), 22-37.

Fleming, J. Clifton Jr., Robert J. Peroni, and Stephen E. Shay, 2009. "Worse Than Exemption." Emory Law Journal 59 (1), 79-149.

Fleischer, Victor, and Nancy Staudt, 2014. "The Supercharged IPO.” Vanderbilt Law Review, forthcoming.

Gilmore, Grant, Jr., and Charles Lund Black, 1975. The Law of Admiralty, 2nd edition. Foundation Press, New York, NY.

Glicklich, Peter A., and Michael J. Miller, 2012. "U.S. Taxation of International Shipping and Air Transport Activities (Portfolio 945).” Bloomberg BNA, Washington, DC, http://www.bna. com/Taxation-International-Shipping-p7754/.

Grubert, Harry, 2012. "Foreign Taxes and the Growing Share of U.S. Multinational Company Income Abroad: Profits, Not Sales, are Being Globalized.” National Tax Journal 65 (2), 247-282. 
Grubert, Harry, and Rosanne Altshuler, 2008. "Corporate Taxes in the World Economy: Reforming the Taxation of Cross-Border Income.” In Diamond, John W., and George R. Zodrow (eds.), Fundamental Tax Reform: Issues, Choices, and Implications, 319-354. MIT Press, Cambridge, MA.

Grubert, Harry, and John Mutti, 2001. Taxing International Business Income: Dividend Exemption Versus the Current System. AEI Press, Washington, DC.

Hanlon, Michelle, and Joel Slemrod, 2009. "What Does Tax Aggressiveness Signal? Evidence From Stock Price Reactions to News About Tax Shelter Involvement." Journal of Public Economics 93 (1-2), 126-141.

Hines Jr., James R., and Eric M. Rice, 1994. "Fiscal Paradise: Foreign Tax Havens and American Business." Quarterly Journal of Economics 109 (1), 149-182.

Howson, Nicholas Calcina, and Vikramaditya S. Khanna, 2010. "The Development of Modern Corporate Governance in China and India." In Sornarajah, Muthucumaraswamy, and Jiangyu Wang (eds.), China, India and the International Economic Order, 513-576. Cambridge University Press, Cambridge, UK.

Isenbergh, Joseph, 2009. International Taxation, 3rd edition. Foundation Press, New York, NY.

Kane, Mitchell A., and Edward B. Rock, 2008. "Corporate Taxation and International Charter Competition." Michigan Law Review 106 (7), 1229-1283.

Kleinbard, Edward D., 2011a. “Stateless Income.” Florida Tax Review 11 (9), 699-774.

Kleinbard, Edward D., 2011b. “The Lessons of Stateless Income.” Tax Law Review 65 (1), 99-171.

Li, Jinyan, 2007. "The Rise and Fall of Chinese Tax Incentives and Implications for International Tax Debates." Florida Tax Review 8 (7), 669-712.

Litvak, Kate, 2007. "The Effect of the Sarbanes-Oxley Act on Non-U.S. Companies Cross-Listed in the U.S." Journal of Corporate Finance 13 (2), 195-228.

Nadal, Lisa, 2009. "New Regulations Likely to Deter Use of Cost-Sharing Arrangements." Tax Notes 122 (2), 191-193.

Ocasal, Christopher, Michael R. Miles, and Carol P. Tello, 2009. "Increased Audit Activity Planned for U.S. Federal Excise Tax on Insurance Premiums." Tax Notes International 54 (6), 503-505.

Organisation for Economic Co-operation and Development, 2000. Towards Global Tax Cooperation: Progress in Identifying and Eliminating Harmful Tax Practices. OECD, Paris, France.

Roin, Julie, 2008. "Can the Income Tax Be Saved? The Promise and Pitfalls of Adopting Worldwide Formulary Apportionment.” Tax Law Review 61 (3), 169-240.

Samuels, John M., 2009. “American Tax Isolationism.” Tax Notes 123 (13), 1593-1599.

Seida, Jim A., and William F. Wempe, 2004. "Effective Tax Rate Changes and Earnings Stripping Following Corporate Inversions.” National Tax Journal 57 (4), 805-828. 
Semenoro, Timothy, 2000. "The State of Our Seafaring Nation: What Course Has Congress Laid for the U.S. Maritime Industry.” Tulane Maritime Law Journal 25 (1), 355-370.

Shaviro, Daniel, 2011. "The Rising Tax Electivity of U.S. Corporate Residence." Tax Law Review 64 (3), 377-430.

Shay, Stephen E., 2004. "Exploring Alternatives to Subpart F.” Taxes 82 (3), 29-38.

Slemrod, Joel, and Marsha Blumenthal, 1996. "The Income Tax Compliance Cost of Big Business." Public Finance Review 24 (4), 411-438.

Solomon, Eric, 2012. "Corporate Inversions: A Symptom of Larger Tax System Problems." Tax Notes 136 (12), 1449-1457.

Sullivan, Martin A., 2011. Corporate Tax Reform: Taxing Profits in the $21^{\text {st }}$ Century. Apress, New York, NY.

U.S. Department of the Treasury, 2002. Corporate Inversion Transactions: Tax Policy Implications. U.S. Department of the Treasury, Office of Tax Policy, Washington, DC.

VanderWolk, Jefferson P., 2010. "Inversions Under Section 7874 of the Internal Revenue Code: Flawed Legislation, Flawed Guidance." Northwestern Journal of International Law and Business 30 (3), 699-719.

Webber, Stuart, 2011. "Inverted U.S. Firms Relocate Headquarters to Europe.” Tax Notes International 64 (8), 589-598.

Wells, Bret, 2012. "Cant and the Inconvenient Truth About Corporate Inversions." Tax Notes 136 (4), 429-439.

White House and U.S. Department of the Treasury, 2012. The President's Framework for Business Tax Reform. White House and U.S. Department of the Treasury, Washington, DC. 